\title{
Amyloid Fibrils Activate Tyrosine Kinase-Dependent Signaling and Superoxide Production in Microglia
}

\author{
Douglas R. McDonald, ${ }^{1}$ Kurt R. Brunden, ${ }^{2}$ and Gary E. Landreth ${ }^{1}$ \\ ${ }^{1}$ Alzheimer Research Laboratory, Department of Neurology and Neurosciences, Case Western Reserve University School \\ of Medicine, Cleveland, Ohio 44106, and 'liatech, Incorporated, Cleveland, Ohio 44122
}

\begin{abstract}
Alzheimer's disease (AD) is a devastating neurological disorder characterized by loss of cognitive skills and progressive dementia. The pathological hallmark of $A D$ is the presence of numerous senile plaques throughout the hippocampus and cerebral cortex associated with degenerating axons, neurofibrillary tangles, and gliosis. The core of the senile plaque primarily is composed of the 39-43 amino acid $\beta$-amyloid peptide $(A \beta)$, which forms fibrils of $\beta$-pleated sheets. Although considerable genetic evidence implicates $A \beta$ in the pathogenesis of $A D$, a direct causal link remains to be established.

Senile plaques are foci of local inflammatory processes, as evidenced by the presence of numerous activated microglia and acute phase proteins. $A \beta$ has been shown to elicit inflammatory responses in microglia; however, the intracellular events mediating these effects are largely unknown. We
\end{abstract}

report that exposure of microglia and THP1 monocytes to fibrillar $A \beta$ led to time- and dose-dependent increases in protein tyrosine phosphorylation of a population of proteins similar to that elicited by classical immune stimuli such as immune complexes. The tyrosine kinases Lyn, Syk, and FAK were activated on exposure of microglia and THP1 monocytes to $A \beta$, resulting in the tyrosine kinase-dependent generation of superoxide radicals. The present data support a role for oxidative damage in the pathogenesis of $A D$, provide an important mechanistic link between $A \beta$ and the generation of reactive oxygen intermediates, and identify molecular targets for therapeutic intervention in AD.

Key words: Alzheimer's disease; $\beta$-amyloid; microglia; THP1 monocytes; signal transduction; tyrosine kinase; inflammatory; superoxide; piceatannol; RAGE; scavenger receptor
Dementia of the Alzheimer type is the most prevalent form of dementia of the aged. The pathological hallmark of Alzheimer's disease $(\mathrm{AD})$ is the presence of numerous senile plaques associated with degenerating neurons, neurofibrillary tangles (Selkoe, 1991), and marked gliosis throughout the hippocampus and cerebral cortex (Itagaki et al., 1989). The senile plaque is composed primarily of the $\beta$-amyloid protein (A $\beta$; Glenner and Wong, 1984; Masters et al., 1985). A $\beta$ is a $39-43$ amino acid peptide derived from the larger amyloid precursor protein (APP) as a result of proteolytic processing (Cole et al., 1989; Golde et al., 1992). A $\beta$ forms fibrils that aggregate and form deposits comprising the core of senile plaques. Considerable genetic evidence has implicated $\mathrm{A} \beta$ in $\mathrm{AD}$ pathogenesis (Selkoe, 1996); however, the relationship between $\mathrm{A} \beta$ and neuronal death and gliosis is incompletely understood.

It has been postulated that the progressive pathology associated with $\mathrm{AD}$ is a consequence of local inflammatory reactions. This view has been supported by clinical studies demonstrating the efficacy of anti-inflammatory drug treatments in reducing the incidence of dementia (McGeer and McGeer, 1996). Microglia, the main immune effector cells within the brain (Leong and Ling, 1992), are the predominant glial cell type present within senile plaques (Itagaki et al., 1989). Microglia that are in direct contact

Received Sept. 24, 1996; revised Jan. 7, 1997; accepted Jan. 15, 1997.

Support for this work was provided by grants from the National Institute on Aging (AG08012) and American Health Assistance Foundation to G.E.L. We thank Drs. Karp Herrup, Patrick McGeer, Bruce Trapp, and Andre Nel for their comments on this manuscript.

Correspondence should be addressed to Dr. Gary Landreth, Alzheimer Research Laboratory, Case Western Reserve University School of Medicine, 10900 Euclid Avenue, Cleveland, OH 44106-4928.

Copyright (C) 1997 Society for Neuroscience $\quad 0270-6474 / 97 / 172284-11 \$ 05.00 / 0$ with senile plaques exhibit an activated phenotype, as evidenced by elevated expression of HLA-DR, complement receptors, and immunoglobulin receptors (McGeer et al., 1989, 1993). In addition, acute phase proteins (Abraham et al., 1988; Griffin et al., 1989; McGeer et al., 1989; Cataldo and Nixon, 1990; Bauer et al., 1991) are present in AD-afflicted brain tissue at significantly elevated levels and are known to be secreted by reactive microglia (Araujo and Cotman, 1992). A critical question concerning the pathogenesis of $\mathrm{AD}$ is whether $\mathrm{A} \beta$ is directly capable of eliciting a local inflammatory response that is damaging to neurons.

The presence of reactive microglia and their secretory products within senile plaques suggest that microglia respond to constituents of the plaques, leading to the acquisition of an activated phenotype. The signal transduction pathways subserving the phenotypic changes mainly are unknown. Importantly, microglia that are in direct contact with senile plaques exhibit high levels of tyrosine-phosphorylated proteins (Wood and Zinsmeister, 1991), suggesting sustained activation of intracellular signaling processes. The activation of tyrosine kinases is the initial step in regulating a variety of cellular processes, including proliferation, differentiation, and inflammatory responses. Numerous inflammatory stimuli are known to activate tyrosine kinases such as Lyn and Syk in monocytes and macrophages, resulting in the release of cytokines and superoxide (Pfefferkorn and Fanger, 1989; Agarwal et al., 1993; Ghazizadeh et al., 1994; Crowley et al., 1996).

We report here that exposure of microglia and THP1 monocytes to fibrillar forms of $\mathrm{A} \beta$ resulted in the activation of tyrosine kinase-dependent intracellular signaling systems and the generation of superoxide radicals. These responses, however, are not linked to scavenger receptors or the receptor for advanced glycation end products, which recently have been shown to bind $\mathrm{A} \beta$. 
These findings support a role for oxidative damage in the pathophysiology of $\mathrm{AD}$ and provide a mechanistic link between $\mathrm{A} \beta$ and the acquisition of an activated phenotype in microglia and the generation of local inflammatory responses. Moreover, identifying signal transduction pathways that are activated on exposure of the cells to $\mathrm{A} \beta$ provides molecular targets for therapeutic interventions in $\mathrm{AD}$.

\section{MATERIALS AND METHODS}

Materials. The anti-phosphotyrosine antibody PY20 and the anti-paxillin $\mathrm{mAb}$ were obtained from Transduction Labs (Lexington, KY). The antiphosphotyrosine antibody 4G10 was obtained from Upstate Biotechnology (Lake Placid, NY). Anti-Fc $\gamma$ RI (mAb 32.2) and anti-Fc $\gamma$ RII (mAb IV.3) were obtained from Medarex (Annendale, NJ). Affinity-purified polyclonal antisera to Lyn, Syk, and FAK were obtained from Santa Cruz Biotechnology (Santa Cruz, CA). Affinity-purified horseradish peroxidase-conjugated goat anti-mouse and goat anti-rabbit antibody was obtained from Boehringer Mannheim (Indianapolis, IN). Goat antimouse $\mathrm{F}(\mathrm{ab})_{2}$ was obtained from Cappel (West Chester, PA) Peptides corresponding to amino acids $25-35$ of $\mathrm{A} \beta$ (A $\beta 25-35)$, amino acids $1-28$ of $A \beta$ (A $\beta 1-28)$, and Substance $P$ were obtained from American Peptide (Sunnyvale, CA). Nonfibrillar A $\beta 1-40$ (Bachem, Philadelphia, PA) was prepared by dissociating fibrils in hexafluoroisopropanol, followed by lyophilization and reconstitution in sterile distilled water, and then used immediately. Fibrillar A $\beta 1-40$ was prepared by reconstitution of the lyophilized peptide in sterile distilled water, followed by incubation for 1 week at $37^{\circ} \mathrm{C}$. A $\beta 1-42$ and scrambled A $\beta 25-35$ (SC25-35; NAMGKILSGIG) were synthesized at Gliatech (Cleveland, OH). All peptides were solubilized in sterile distilled $\mathrm{H}_{2} \mathrm{O}$. Serum amyloid A, human LDL, and acetylated human LDL were kind gifts of Dr. Frederick DeBeer (University of Kentucky). LPS, ferricytochrome C type III, nitroblue tetrazolium (NBT), and superoxide dismutase were obtained from Sigma (St. Louis, MO). Protein A-agarose, fatty acid-free BSA, and piceatannol were obtained from Boehringer Mannheim. BSA was maleylated as previously described (Haberland and Fogelman, 1985).

Cell culture. THP-1 cells were maintained in RPMI-1640 (Whittaker Bioproducts, Walkersville, MD) supplemented with $10 \%$ heat-inactivated fetal calf serum (FCS), $5 \times 10^{-5}$ M 2-mercaptoethanol, $5 \mathrm{~mm}$ HEPES, and $1.5 \mu \mathrm{g} / \mathrm{ml}$ gentamicin in an atmosphere of $5 \% \mathrm{CO}_{2}$. Jurkat cells were maintained in the the same medium but without 2-mercaptoethanol. Microglia and astrocytes were derived from the brains of neonatal rats as previously described but with some modifications (Giulian and Baker, 1986). Cerebral cortices were isolated from postnatal day 0 (P0) Sprague Dawley rats, and meninges and blood vessels were removed completely. Cortices were minced with a sterile razor blade, and cells were dissociated in PBS containing $0.25 \%$ trypsin and $1 \mathrm{~mm}$ EDTA for $30 \mathrm{~min}$ at $25^{\circ} \mathrm{C}$. Digestion was terminated by adding an equal volume of DMEM/F12 medium (Life Technologies, Gaithersburg, MD) containing 20\% FCS, and cells were triturated to obtain a single-cell suspension. Cells were plated in $75 \mathrm{~mm}$ flasks coated with poly-L-lysine $(0.1 \mathrm{mg} / \mathrm{ml}$; Sigma $)$ at a density of $5 \times 10^{7}$ cells per flask. Media were replaced the next day with DMEM/F12 containing 20\% FCS. Cells were grown for $7 \mathrm{~d}$ without changing the medium to allow microglial proliferation. Microglia were harvested by shaking for $30 \mathrm{~min}$ on a rotary shaker at $120 \mathrm{rpm}$. Purity of cultures was determined by staining with the microglial marker Griffonia simplicifolia Isolectin B4 (Sigma). Astrocytes were recovered after removal of microglia and passaged three times, generating highly enriched cultures of astrocytes.

Cell stimulation. Tissue culture dishes were coated with nitrocellulose (Lagenaur and Lemmon, 1987) and derivatized by adding $48 \mathrm{pmol} / \mathrm{mm}^{2}$ A $\beta$ peptides in distilled water and allowed to dry. Microglia $\left(5 \times 10^{6}\right.$ cells $)$, astrocytes $\left(5 \times 10^{6}\right.$ cells $)$, THP- 1 cells $\left(1 \times 10^{7}\right)$, and Jurkat cells $\left(1 \times 10^{7}\right.$ cells $)$ were resuspended in $1 \mathrm{ml}$ of HBSS and added to underivatized dishes or dishes derivatized with immobilized peptide for 5 min. In some cases the cells were stimulated by adding peptides or stimulants in solution. High-affinity ( $\mathrm{Fc} \gamma \mathrm{RI})$ and low-affinity (Fc $\gamma \mathrm{RII})$ immunoglobulin receptors were cross-linked by incubation of $1 \times 10^{7}$ THP1 monocytes with $2 \mu \mathrm{g}$ of anti-Fc $\gamma$ RI or anti-Fc $\gamma$ RII in ice-cold RPMI for $30 \mathrm{~min}$. Cells were pelleted and resuspended in HBSS $\left(37^{\circ} \mathrm{C}\right)$ in the absence or presence of $10 \mu \mathrm{g}$ of goat anti-mouse $\mathrm{F}(\mathrm{ab})_{2}$ for $5 \mathrm{~min}$. Then cells were lysed in $0.5 \mathrm{ml}$ of ice-cold Triton buffer [ $1 \%$ Triton X-100 and (in mM): 10 Tris, pH 7.4, $140 \mathrm{NaCl}, 1 \mathrm{Na}_{3} \mathrm{VO}_{4}, 10 \mathrm{NaF}, 1$ EDTA, 1 EGTA, and 2 PMSF].
Immunoprecipitation and Western blotting. Protein content of lysates was quantitated by the method of Bradford, using BSA as a standard (Bradford, 1976). Triton buffer lysates were precleared by incubation with $10 \mu \mathrm{l}$ of protein A-agarose for $30 \mathrm{~min}$ and then incubated with 1 $\mu \mathrm{g}$ of antibody per milligram of lysate protein for $2 \mathrm{hr}$, followed by adding $10 \mu \mathrm{l}$ of $50 \%(\mathrm{v} / \mathrm{v})$ protein A-agarose for $1 \mathrm{hr}$ at $4^{\circ} \mathrm{C}$. The immunoprecipitates were washed three times in lysis buffer. In some instances the phosphotyrosine-containing proteins were eluted from the immune complex by adding $40 \mathrm{~mm} p$-nitrophenylphosphate (PNP). Otherwise, the immune complexes were solubilized directly in Laemmli sample buffer, boiled for $5 \mathrm{~min}$, and then resolved by SDS/PAGE under reducing conditions. For Western blot analysis of Lyn, cells were lysed in $300 \mu \mathrm{l}$ of ice-cold RIPA buffer ]1\% Triton, $0.1 \%$ SDS, $0.5 \%$ deoxycholate, and (in mM): 20 Tris, $\mathrm{pH} 7.4,150 \mathrm{NaCl}, 10 \mathrm{NaF}, 1$ $\mathrm{Na}_{3} \mathrm{VO}_{4}, 1$ EDTA, 1 EGTA, and 2 PMSF]. Insoluble material was removed by centrifugation at $10,000 \times g$ at $4^{\circ} \mathrm{C}$ for $10 \mathrm{~min}$. Laemmli sample buffer was added to RIPA lysates, which were resolved by SDS/PAGE under reducing conditions. The proteins were transferred to PolyScreen membranes (DuPont NEN, Boston, MA) and then blocked in TBS-T (10 mM Tris, pH 7.5, $100 \mathrm{~mm} \mathrm{NaCl}$, and $0.05 \%$ Tween 20) containing $3 \% \mathrm{BSA}$ overnight at $4^{\circ} \mathrm{C}$. The blots were incubated with the appropriate primary antibody for $1 \mathrm{hr}$, washed three times in TBS-T, incubated for $1 \mathrm{hr}$ with goat anti-mouse or goat anti-rabbit antibodies conjugated to HRP in TBS-T plus $5 \%$ nonfat dried milk, and washed three times in TBS-T, followed by detection with an enhanced chemiluminescence (ECL) detection system (DuPont NEN). In some instances blots were stripped by incubation for $30 \mathrm{~min}$ at $50^{\circ} \mathrm{C}$ in stripping buffer (62.5 mM Tris, $\mathrm{pH} 6.8,100 \mathrm{~mm} \beta$-mercaptoethanol, and $2 \%$ SDS) and reprobed with other antibodies.

Tyrosine kinase assays. THP1 monocytes were stimulated with $\mathrm{A} \beta 25$ 35 , and tyrosine-phosphorylated proteins were immunoprecipitated with PY20 as described above. Tyrosine kinase activity then was assayed by phosphorylation of polyGluTyr (PGT; 4:1 Glu, Tyr; Sigma) (Guan and Shalloway, 1992). PGT assays were performed by adding $10 \mu \mathrm{l}(0.1 \mu \mathrm{g})$ aliquots of phosphotyrosine-containing proteins eluted with $100 \mu \mathrm{l}$ of Triton buffer containing $40 \mathrm{~mm}$ PNP, which were added to $40 \mu \mathrm{l}$ of PGT kinase buffer (50 mM Tris, $\mathrm{pH} 7.4,10 \mathrm{mM} \mathrm{MnCl}_{2}, 10 \mu \mathrm{M}$ ATP, and 30 $\left.\mathrm{cpm} / \mathrm{fmol}\left[{ }^{32} \mathrm{P}\right] \mathrm{ATP}\right)$ and incubated at $25^{\circ} \mathrm{C}$ for $30 \mathrm{~min}$. Reactions were terminated by adding Laemmli sample buffer and were boiled for $5 \mathrm{~min}$. Samples were resolved by SDS/PAGE under reducing conditions, and radioactivity was quantitated by Cerenkov counting.

In vitro kinase assays were performed with THP1 monocytes, which were grown for $2 \mathrm{~d}$ in media alone or supplemented with $50 \mathrm{ng} / \mathrm{ml}$ lipopolysaccharide (LPS; Sigma), and then stimulated as described above and lysed in Triton buffer (Ghazizadeh et al., 1994). Phosphotyrosinecontaining proteins were immunoprecipitated, and the immunoprecipitates were washed three times in Triton buffer and once in HEPES buffer containing (in mM) 25 HEPES, pH 7.4, $150 \mathrm{NaCl}$, and $1 \mathrm{Na}_{3} \mathrm{VO}_{4}$, followed by incubation in kinase buffer (25 mM HEPES, pH 7.4, $10 \mathrm{~mm}$ $\mathrm{MnCl}_{2}, 1 \mu \mathrm{M}$ ATP, and $\left.150 \mathrm{cpm} / \mathrm{fmol}\left[{ }^{32} \mathrm{P}\right] \mathrm{ATP}\right)$ for $5 \mathrm{~min}$ at $25^{\circ} \mathrm{C}$ in a final volume of $40 \mu$ l. Reactions were terminated by adding Laemmli buffer and were boiled for $5 \mathrm{~min}$. Incorporated radioactivity was quantitated by Cerenkov counting of the excised gel lane.

The enzymatic activity of Lyn was analyzed from unstimulated THP1 monocytes or THP1 monocytes stimulated on $60 \mathrm{pmol} / \mathrm{mm}^{2}$ surface-bound A $325-35$ (Ghazizadeh et al., 1994). ${ }^{32}$ P-labeled anti-phosphotyrosine immune complexes were obtained as described for in vitro kinase assays. Reactions were terminated, and immune complexes were dissociated by adding $70 \mu \mathrm{l}$ of Triton buffer containing 3\% SDS and were boiled for $3 \mathrm{~min}$. Eluted proteins were diluted 10 -fold with Triton buffer and reimmunoprecipitated with $1 \mu \mathrm{g}$ of anti-Lyn antisera and $10 \mu \mathrm{l}$ of protein A-agarose for 3 hr. Proteins were resolved by SDS/PAGE under reducing conditions, and ${ }^{32} \mathrm{P}$-labeled proteins were detected by autoradiography.

Measurement of superoxide production. $\mathrm{O}_{2}^{-}$production was measured by the reduction of ferricytochrome $\mathrm{C}$, as previously described (Pick, 1986). Microglia $\left(2 \times 10^{5}\right.$ cells $)$ were added to 48 -well tissue culture dishes and allowed to adhere overnight, whereas THP1 monocytes $(5 \times$ $10^{5}$ cells) were added to dishes in $0.5 \mathrm{ml}$ HBSS containing $80 \mu \mathrm{M}$ ferricytochrome $\mathrm{C}$ type III immediately before use. Media were removed from microglia, and stimulants were added in $0.5 \mathrm{ml}$ of HBSS containing $80 \mu \mathrm{M}$ ferricytochrome C type III (Sigma) in duplicate and incubated for $90 \mathrm{~min}$. Stimulants were added directly to the THP1 monocytes in duplicate and incubated for $90 \mathrm{~min}$. The specificity of the reaction was verified by adding $40 \mu \mathrm{g}$ of superoxide dismutase (Sigma) to one set of samples. In some instances THP1 monocytes and micro- 
glia were pretreated for $1 \mathrm{hr}$ with $25 \mu \mathrm{g} / \mathrm{ml}$ piceatannol, followed by stimulation of the cells with peptides in the presence of piceatannol. The medium was collected, and production of superoxide was determined spectrophotometrically by measurement of the reduction of ferricytochrome $\mathrm{C}$ at $550 \mathrm{~nm}$ and converted to moles of $\mathrm{O}_{2}^{-}$, using an extinction coefficient of $21 \times 10^{3} \mathrm{M}^{-1} \mathrm{~cm}^{-1}$. Production of $\mathrm{O}_{2}^{-}$is expressed as nanomole $\mathrm{O}_{2}^{-}$per 90 min per $2 \times 10^{5}$ cells. Intracellular production of $\mathrm{O}_{2}^{-}$was assayed by the reduction of NBT, as previously described (Pick, 1986). THP1 monocytes $\left(1 \times 10^{6}\right)$ were suspended in $0.5 \mathrm{ml}$ of HBSS containing $1 \mathrm{mg} / \mathrm{ml} \mathrm{NBT}$. Stimulants were added to cells, followed by incubation at $37^{\circ} \mathrm{C}$ for $10 \mathrm{~min}$. Cells were pelleted rapidly, supernatants were removed, and cells were lysed by sonication in RIPA buffer to release reduced NBT precipitates. Reduction of NBT was measured by the change in absorbance at $550 \mathrm{~nm}$. Cells treated with vehicle only served as blanks. Assays were performed in duplicate.

\section{RESULTS}

\section{$A \beta$ stimulates tyrosine phosphorylation in microglia and THP1 monocytes}

We tested whether $A \beta$ could initiate intracellular signaling events via the stimulation of the activity of tyrosine kinases by exposing primary cultures of rat microglia and astrocytes, as well as human THP1 monocytes and Jurkat cells, to $\mathrm{A} \beta$ peptides that had been immobilized on the surface of tissue culture dishes. The interaction of microglia and THP1 monocytes with A $\beta 1-40$ or a peptide derived from the $\mathrm{C}$ terminus of $\mathrm{A} \beta, \mathrm{A} \beta 25-35$, elicited a rapid and dramatic increase in tyrosine phosphorylation of a similar population of proteins (Fig. 1 $A, B$ ). Astrocytes and Jurkat cells were unresponsive, demonstrating that $\mathrm{A} \beta$-stimulated protein tyrosine phosphorylation was specific to cells within the microglial lineage (Fig. $1 A$ ).

$\mathrm{A} \beta$ contained within senile plaques primarily consists of $\mathrm{A} \beta 1-42$ and $\mathrm{A} \beta 1-40$ in a fibrillar $\beta$-pleated sheet conformation (Masters et al., 1985). THP1 monocytes were exposed to fibrillar $A \beta 1-42$ and $A \beta 1-40$, which had been immobilized on tissue culture dishes. $A \beta$ induced markedly elevated levels of protein tyrosine phosphorylation (Fig. $1 B$ ). Then the biologically active domain within $\mathrm{A} \beta$ was defined with peptides derived from the $N$ terminus $(\mathrm{A} \beta 1-28)$ and $\mathrm{C}$ terminus $(\mathrm{A} \beta 25-$ 35 ) of $\mathrm{A} \beta$. The active domain of $\mathrm{A} \beta$ was found to be restricted to amino acids $25-35$, a region capable of forming $\beta$-pleated sheets (Terzi et al., 1994). Control peptides included scrambled A $325-35$ (SC25-35), substance P (SP), fibronectin, and serum amyloid A (SAA). These peptides elicited no alteration in protein tyrosine phosphorylation.

The dependence of the conformation of $\mathrm{A} \beta$ on its ability to induce tyrosine phosphorylation in THP1 monocytes was examined. A fibrillar conformation of A $\beta 25-35$ was far more effective in stimulating tyrosine phosphorylation than nonfibrillar A $\beta 25-35$ (Fig. 1C). Similarly, the activation of tyrosine kinase activity was dependent on exposure of the cells to fibrillar A $\beta 1-40$ (Fig. $1 D$ ). Exposure of the cells to nonfibrillar A $\beta 1-40$ had no effect on the enzymatic activity of tyrosine kinases. These observations are consistent with previous studies, which have shown that a fibrillar confirmation of $\mathrm{A} \beta$ is critical for biological responses such as neurotoxicity (Pike et al., 1990) and stimulation of IL- $1 \beta$ release from THP1 monocytes (Lorton et al., 1996).

\section{Time course and dose-response of $\mathbf{A} \boldsymbol{\beta}$-stimulated tyrosine phosphorylation}

Exposure of THP1 monocytes to surface-bound $\mathrm{A} \beta$ rapidly stimulated protein tyrosine phosphorylation, reaching maximal levels in $5 \mathrm{~min}$ and returning to basal levels by $30 \mathrm{~min}$, as measured by Western blot analysis with anti-phosphotyrosine antibodies. A $\beta$-induced tyrosine kinase activity was measured in parallel assays by an enzymatic assay of the tyrosine kinases by phosphorylation of the substrate PGT. A $\beta$ stimulated rapid activation of tyrosine kinase activity with similar kinetics, reaching peak levels in 5 min (Fig. $2 A$ ). We did not consistently observe significant increases in tyrosine kinase activity from 30 to $60 \mathrm{~min}$.

The dose-response of $\mathrm{A} \beta$-stimulated tyrosine phosphorylation was examined. The response of THP1 monocytes to surface-bound fibrillar $\mathrm{A} \beta$ or fibrillar $\mathrm{A} \beta$ in solution was compared. Fibrillar A $\beta 25-35$ added in solution to THP1 monocytes stimulated maximal tyrosine phosphorylation between $80-100$ $\mu \mathrm{M}$ A $\beta 25-35$, and surface-bound A $\beta 25-35$ stimulated maximal levels of tyrosine phosphorylation in THP1 monocytes at a peptide density between $80-100 \mathrm{pmol} / \mathrm{mm}^{2}$ (Fig. $2 B$ ). However, fibrillar $\mathrm{A} \beta$ added in solution consistently stimulated greater increases in tyrosine phosphorylation at lower quantities of peptide than surface-bound $\mathrm{A} \beta$. This observation may suggest that $A \beta$ in solution is more potent than surface-bound $\mathrm{A} \beta$ or that similar quantities of $\mathrm{A} \beta$ may be more accessible to cells in solution than bound to a surface. We did not consistently detect any further stimulation of tyrosine phosphorylation at higher levels of peptides (data not shown). The maximal response was elicited by similar quantities of A $\beta 25-35$ presented to THP1 monocytes in suspension $(1 \mathrm{ml}, 80 \mu \mathrm{M}=80$ $\mathrm{nmol})$ or surface-bound $\left(80 \mathrm{pmol} / \mathrm{mm}^{2}=77 \mathrm{nmol}\right)$. Repeated examination of $\mathrm{A} \beta$-stimulated tyrosine phosphorylation did not reveal significant qualitative or quantitative differences in the populations of tyrosine-phosphorylated proteins observed in THP1 monocytes when stimulated with maximal quantities of $\mathrm{A} \beta$ in solution or bound to a surface.

\section{$A \beta$ and activation of immunoglobulin $G$ receptors elicits tyrosine phosphorylation of a common population of proteins}

Monocytes respond to a variety of immune stimuli by activation of tyrosine kinases. A direct comparison of the response of THP1 monocytes to $\mathrm{A} \beta$ and to activation of the high- and low-affinity immunoglobulin receptors (Fc $\gamma \mathrm{RI}$ and $\mathrm{Fc} \gamma \mathrm{RII}$ ) revealed that these stimuli induced phosphorylation of a similar population of proteins, suggesting that $\mathrm{A} \beta$ activates common elements within an inflammatory response pathway (Fig. 3). Therefore, we initiated studies to establish the identities of several of the tyrosine kinases activated on exposure of microglia and THP1 monocytes to A $\beta$.

\section{Identification of $\mathbf{A} \boldsymbol{\beta}$-stimulated tyrosine-phosphorylated proteins}

Activation of monocytes by immune stimuli, such as Fc $\gamma \mathrm{RI}$ and Fc $\gamma$ RII cross-linking, results in the activation of Src family tyrosine kinases such as Lyn (Kiener et al., 1993; Ghazizadeh et al., 1994). To determine whether A $\beta$ activated Lyn, we exposed microglia and THP1 monocytes to A $\beta 25-35$. Src family tyrosine kinases have been shown to associate with the Triton-insoluble cytoskeleton (Clark and Brugge, 1993), so Lyn was extracted from the cytoskeleton by incubation in RIPA buffer. RIPA lysates were analyzed by Western blot with anti-phosphotyrosine $\mathrm{mAb}$, followed by stripping the blot and reprobing with anti-Lyn antisera. In parallel assays, the effect of $A \beta 25-35$ on the enzymatic activity of Lyn was examined from Triton lysates of THP1 monocytes that were sonicated briefly to disrupt cytoskeleton. Lysates were immunoprecipitated with anti-phosphotyrosine $\mathrm{mAb}$, and immunoprecipitates were incubated with $\left[{ }^{32} \mathrm{P}\right] \mathrm{ATP} .{ }^{32} \mathrm{P}$-labeled proteins 
A.

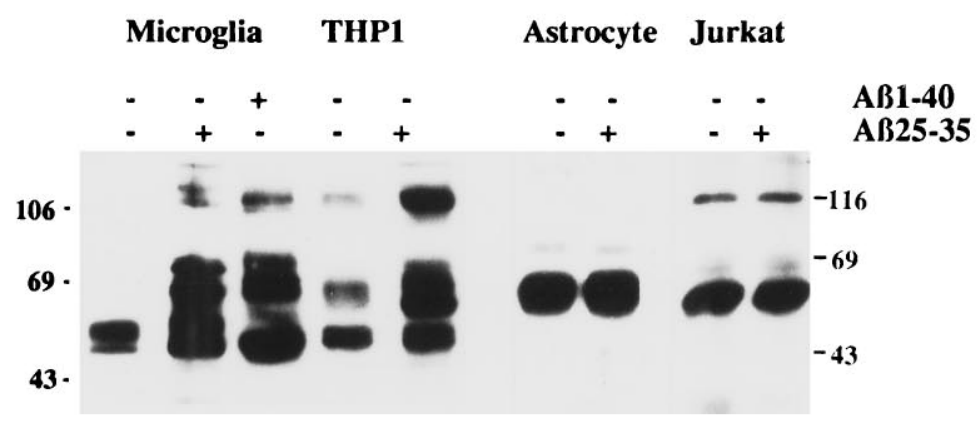

B.

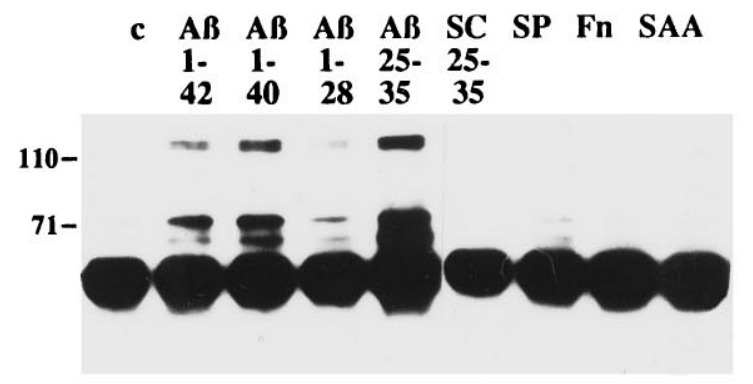

C.

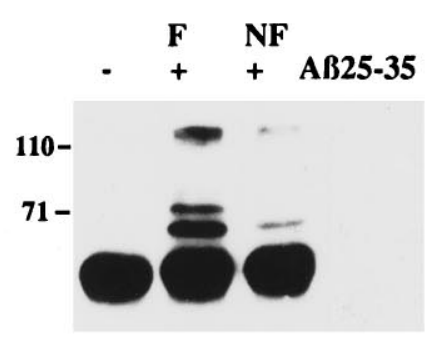

D.

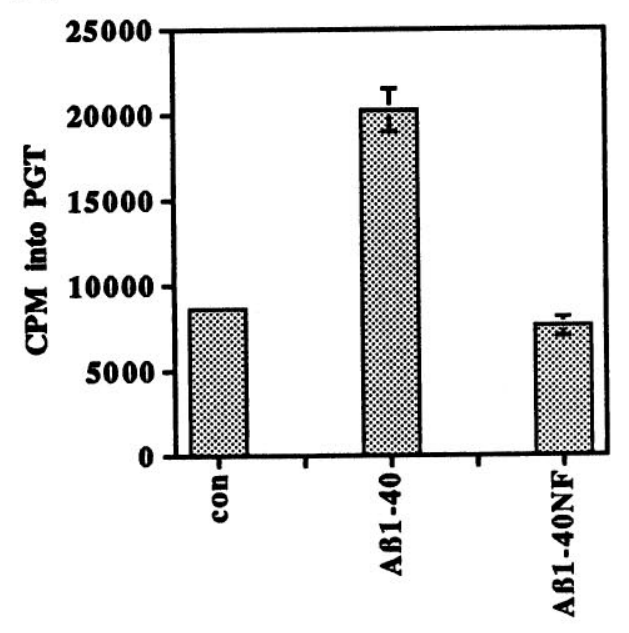

Figure 1. Fibrillar $\mathrm{A} \beta$ peptides stimulate increased tyrosine phosphorylation and tyrosine kinase activity in microglia and THP1 monocytes. $A$, Exposure of microglia and THP1 monocytes, but not astrocytes and Jurkat cells, to $\mathrm{A} \beta$ peptides leads to increased protein tyrosine phosphorylation. Western blot analysis of tyrosine phosphoproteins was performed on phosphotyrosine immunoprecipitates from primary rat microglia and astrocytes, human THP1 monocytes, and Jurkat T-lymphocytes. The cells were exposed for $5 \mathrm{~min}$ to $\mathrm{A} \beta$ peptides $\left(48 \mathrm{pmol} / \mathrm{mm}^{2}\right)$ immobilized on the surface of tissue culture dishes or to an underivatized surface. The broad band at $55 \mathrm{kDa}$ is $\operatorname{IgG}$ heavy chain. $B$, Ligand specificity of $\mathrm{A} \beta$-stimulated tyrosine phosphorylation in THP1 monocytes. Tissue culture dishes were underivatized $(c)$ or derivatized with $48 \mathrm{pmol} / \mathrm{mm}^{2} A \beta 1-42, A \beta 1-$ 40, $A \beta 1-28, A \beta 25-35$, scrambled A $\beta 25-35$ (SC25-35; NAMGKILSGIG), substance P $(S P)$, serum amyloid A $(S A A)$, or $20 \mu \mathrm{g} / \mathrm{ml}$ fibronectin $(F n)$. THP1 monocytes were exposed to the immobilized substrates or an underivatized surface for $5 \mathrm{~min}$, followed by Western blot analysis with anti-phosphotyrosine antibodies. The broad band at $55 \mathrm{kDa}$ is $\mathrm{IgG}$ heavy chain. $C$, Stimulation of protein tyrosine phosphorylation in THP1 monocytes by fibrillar $\mathrm{A} \beta 25-35$, but not nonfibrillar $\mathrm{A} \beta 25-35$. THP1 monocytes were incubated for $5 \mathrm{~min}$ in the absence (-) or presence $(+)$ of $20 \mu \mathrm{M}$ fibrillar $(F)$ $\mathrm{A} \beta 25-35$ or nonfibrillar $(N F) \mathrm{A} \beta 25-35$ in suspension. Western blot analysis of tyrosine phosphoproteins was performed on phosphotyrosine immunoprecipitates. The broad band at $55 \mathrm{kDa}$ is $\operatorname{IgG}$ heavy chain. $D$, Fibrillar A $\beta 1-40$ stimulates tyrosine kinase activity in THP1 monocytes. Tyrosine kinase activity in THP1 monocytes was measured after a 5 min exposure of the cells to fibrillar $A \beta 1-40$ or nonfibrillar A $\beta 1-40$ ( $A \beta 1-$ $40 N F$ ) immobilized on a dish. Tyrosine kinase activity was measured from phosphotyrosine immunoprecipitates, with polyGluTyr as a substrate. Proteins were resolved by SDS-PAGE, the gel was dried, and the lanes were cut and subjected to Cerenkov counting. The positions of the molecular weight standards $(\mathrm{kDa})$ are indicated. were eluted from immune complexes by boiling 3 min in Triton buffer containing 3\% SDS and were diluted 10-fold in Triton buffer. The proteins were reimmunoprecipitated with anti-Lyn antisera, and immunoprecipitates were resolved by SDS-PAGE and analyzed by autoradiography. Exposure of microglia and THP1 monocytes to A $\beta 25-35$ stimulated both the tyrosine phosphorylation and enzymatic activity of Lyn (Fig. 4A,B).

The cytosolic tyrosine kinase Syk is an important signaling component that is tyrosine-phosphorylated and enzymatically ac- tivated by a variety of inflammatory stimuli in monocytes and macrophages (Greenburg et al., 1994; Crowley et al., 1996). A $\beta$ stimulation of microglia and THP1 monocytes led to increased tyrosine phosphorylation of Syk (Fig. 4A,B). Pretreatment of THP1 monocytes with piceatannol, a tyrosine kinase inhibitor that preferentially inhibits Syk (Oliver et al., 1994), significantly reduced $\mathrm{A} \beta$-stimulated tyrosine phosphorylation of a subset of cellular proteins, which included $\mathrm{p} 72^{\text {Syk }}$ (Fig. 4C). Thus, $\mathrm{A} \beta$ activated the tyrosine kinases, Lyn and Syk, which are the most 
A.

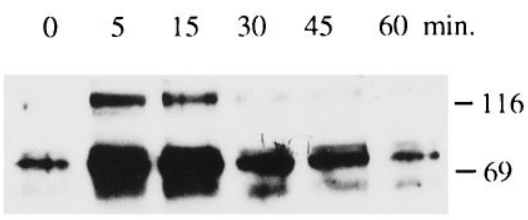

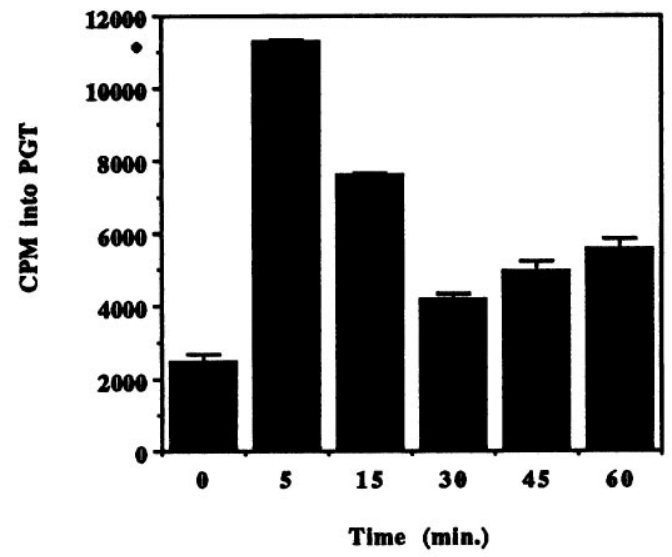

Figure 2. Time course and dose-response of A $325-35$-stimulated tyrosine phosphorylation in THP1 monocytes. $A$, THP1 monocytes were stimulated for the indicated times on $60 \mathrm{pmol} / \mathrm{mm}^{2} \mathrm{~A} \beta 25-35$ bound to tissue culture dishes. Tyrosine-phosphorylated proteins were immunoprecipitated with antiphosphotyrosine mAb (PY20), followed by elution with $40 \mathrm{~mm} p$-nitrophenylphosphate. Proteins $(0.6 \mu \mathrm{g})$ were resolved by SDSPAGE, transferred to polyvinylidene fluoride (PVDF), and subjected to Western blot with anti-phosphotyrosine mAb (PY20). In parallel assays, proteins $(0.1 \mu \mathrm{g})$ were analyzed in a kinase assay by phosphorylation of the tyrosine kinase substrate polyGluTyr $(P G T)$. $B$, THP1 monocytes were stimulated with the indicated quantities of $A \beta 25-35$, surfacebound or in solution, for $5 \mathrm{~min}$. Tyrosinephosphorylated proteins were immunoprecipitated with anti-phosphotyrosine mAb (PY20), resolved by SDS-PAGE, transferred to PVDF, and subjected to Western blot with anti-phosphotyrosine mAb (4G10). The broad band at $55 \mathrm{kDa}$ is $\operatorname{IgG}$ heavy chain.

\section{B.}

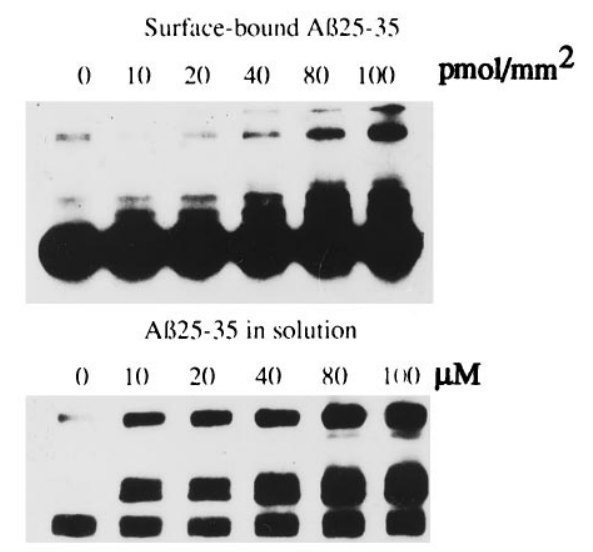

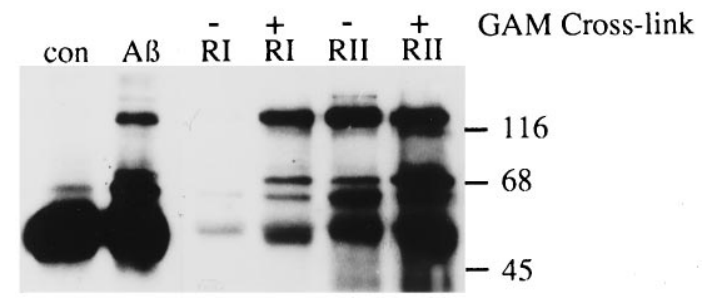

Figure 3. Comparison of tyrosine phosphorylation in THP1 monocytes stimulated with $A \beta, \mathrm{Fc} \gamma \mathrm{RI}(R I)$, or Fc $\gamma \mathrm{RII}(R I I)$. THP1 monocytes were stimulated for $5 \mathrm{~min}$ with $60 \mathrm{pmol} / \mathrm{mm}^{2} \mathrm{~A} \beta 25-35$ bound to a tissue culture dish, mAb 32.2 (anti-Fc $\gamma \mathrm{RI}$ ), mAb 32.2 (anti-Fc $\gamma \mathrm{RI}$ ) cross-linked with goat anti-mouse $\mathrm{F}(\mathrm{ab})_{2}$, mAb IV.3 (anti-Fc $\gamma \mathrm{RII}$ ), or mAb IV.3 (anti$\mathrm{Fc} \gamma \mathrm{RII})$ cross-linked with goat anti-mouse $\mathrm{F}(\mathrm{ab})_{2}$. Tyrosine phosphoproteins were analyzed by immunoprecipitation, followed by Western blot with anti-phosphotyrosine mAb (4G10).

proximal catalytic elements comprising a signal transduction pathway mediating the activation of these cells.

Microglia are the predominant glial cell type found within the senile plaques (Itagaki et al., 1989), suggesting that microglia are likely to migrate to and interact with these structures. The cytosolic tyrosine kinase, FAK, has been shown to be important in cellular adhesion, migration, and inflammatory responses (Furuta et al., 1995; Hamawy et al., 1995; Ilic et al., 1995). Examination of phosphotyrosine-labeled proteins from
A $\beta$-stimulated microglia and THP1 monocytes revealed a prominent $125 \mathrm{kDa}$ phosphoprotein, the tyrosine phosphorylation of which was stimulated markedly by exposure to $\mathrm{A} \beta$ bound to surfaces or added in solution (Fig. 2B). This protein was identified as $\mathrm{p} 125^{\mathrm{FAK}}$ by immunoprecipitation with anti-FAK antisera, followed by anti-phosphotyrosine blot (Fig. 4A,B).

One of the primary targets of FAK and the src family tyrosine kinases such as Lyn is the cytoskeletal-associated protein, paxillin (Minoguchi et al., 1994; Bellis et al., 1995). Paxillin has been shown to be involved in linking membrane proteins and signaling molecules to the actin cytoskeleton and colocalizes at focal adhesions and phagolysosomes in macrophages (Greenburg et al., 1994). Exposure of microglia and THP1 monocytes to A $\beta 25-35$ resulted in a dramatic stimulation of the tyrosine phosphorylation of paxillin in both cell types (Fig. $4 A, B$ ).

\section{Stimulation of respiratory burst in microglia and THP1 monocytes by $A \beta$}

To establish whether $A \beta$ is capable of directly activating microglia and stimulating the release of potentially harmful inflammatory products, we studied the effects of $\mathrm{A} \beta$ on the production of superoxide radicals in microglia and THP1 monocytes. Adding A $\beta$ peptides to microglia and THP1 monocytes resulted in the production of $\mathrm{O}_{2}^{-}$, which was blocked by the presence of superoxide dismutase (Fig. $5 A$ ). The stimulation of $\mathrm{O}_{2}^{-}$release was 
A. Microglia

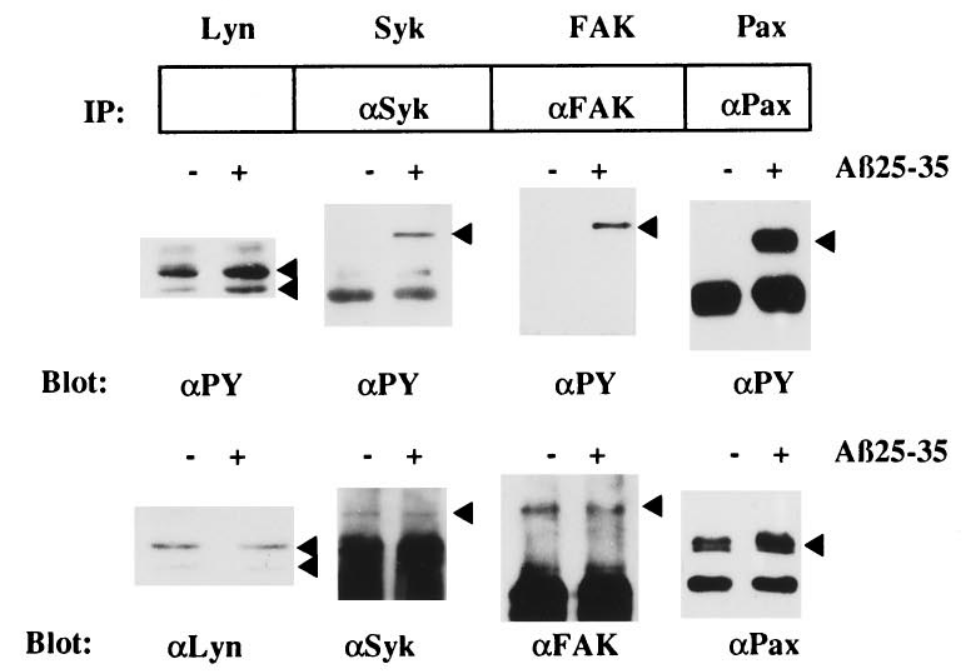

\section{B. THP1 Monocytes}

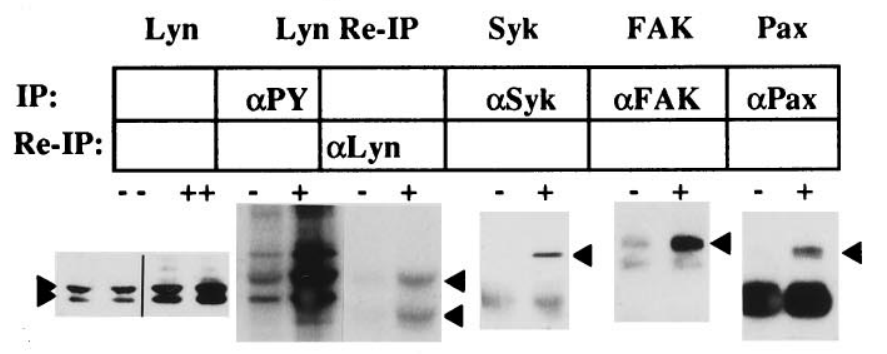

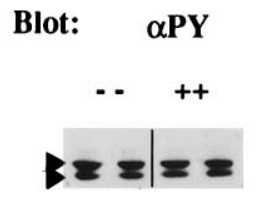

Blot: $\alpha \mathbf{L y n}$

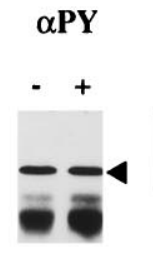

$\alpha$ Syk $\alpha \mathbf{P Y}$

$\alpha \mathbf{P Y}$

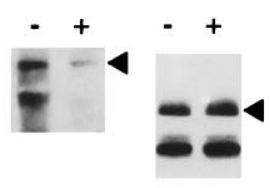

$\alpha$ FAK

$\alpha \mathbf{P a x}$
C.

\begin{tabular}{rl|c|c|c|}
\hline $\mathbf{0}$ & $\mathbf{0}$ & $\mathbf{2 5}$ & $\mathbf{5 0}$ \\
\hline- & + & + & + \\
\hline & \\
& \\
& \\
& $=-\infty-\infty$
\end{tabular}

$\mu \mathrm{g} / \mathrm{ml}$ piceatannol

50 $\mu$ M AB25-35 dependent on addition of fibrillar $\mathrm{A} \beta 1-40$ and $\mathrm{A} \beta 25-35$. Adding nonfibrillar $A \beta 25-35$ to microglia stimulated $50 \%$ less $\mathrm{O}_{2}^{-}$production than fibrillar $\mathrm{A} \beta 25-35$, and this modest response is most likely a consequence of aggregation of $\mathrm{A} \beta 25-35$ during the $90 \mathrm{~min}$ time course of the assay (Fig. 5B; Terzi et al., 1994). Importantly,
Bead

only

$+\mathbf{A B 2 5 - 3 5}$

$\alpha \mathbf{P Y}$

AB25-35
Figure 4. Identification of A $\beta 25-35$-stimulated tyrosine-phosphorylated proteins in microglia and THP1 monocytes and the effect of the tyrosine kinase inhibitor piceatannol. $A, \mathrm{~A} \beta 25-35$-stimulated tyrosine phosphorylation of $L y n, S y k, F A K$, and paxillin $(P a x)$ in primary cultures of rat microglia. $B$, THP1 monocytes were evaluated by immune precipitation and Western blot analysis with the indicated antibodies. Lyn identification and enzymatic activation in THP1 monocytes also was evaluated by immunoprecipitation with an antiphosphotyrosine antibody, followed by incubation of the immune complex with $\left[{ }^{32} \mathrm{P}\right] \mathrm{ATP}$. The radiolabeled Lyn was released from the immune complex and then reprecipitated with an anti-Lyn antibody and visualized by autoradiography. Arrowheads denote migration of the respective proteins. $C$, THP1 monocytes were pretreated for $1 \mathrm{hr}$ with the indicated amounts of piceatannol. Then cells were exposed to $50 \mu \mathrm{M} \mathrm{A} \beta 25-35$ for 5 min. Cellular lysates were resolved by SDS-PAGE, transferred to PVDF, and subjected to Western blot with anti-phosphotyrosine mAb (4G10). pretreatment of microglia and THP1 monocytes with piceatannol, the Syk-selective tyrosine kinase inhibitor, blocked the production of superoxide, demonstrating that $\mathrm{A} \beta$-stimulated superoxide production is linked to the activation of Syk or kinases downstream of Syk (Fig. 5C). 
A.

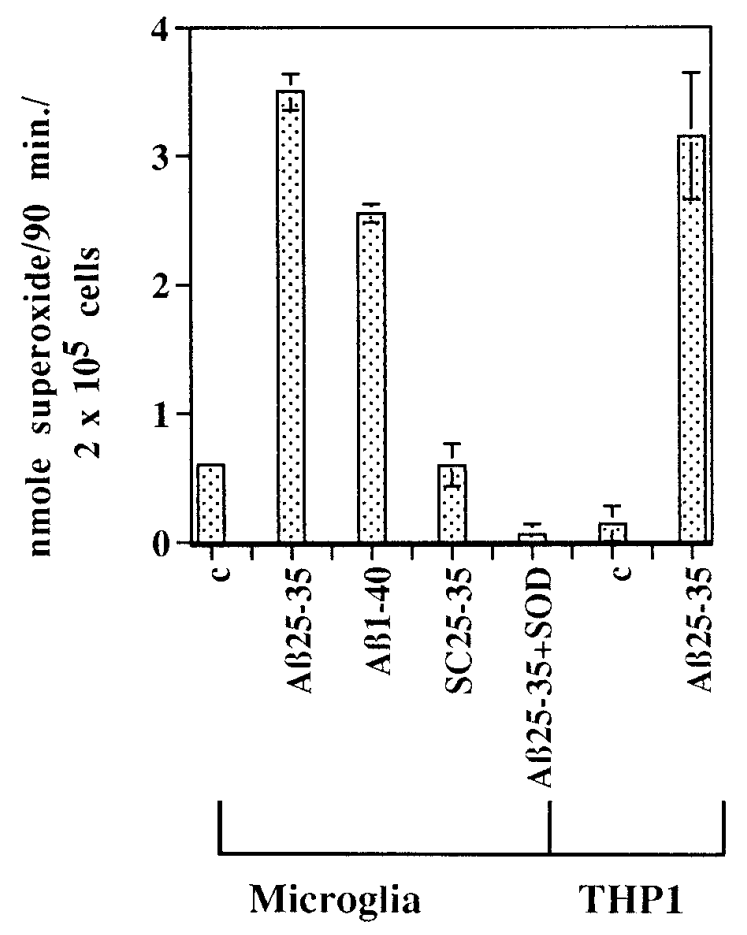

C.

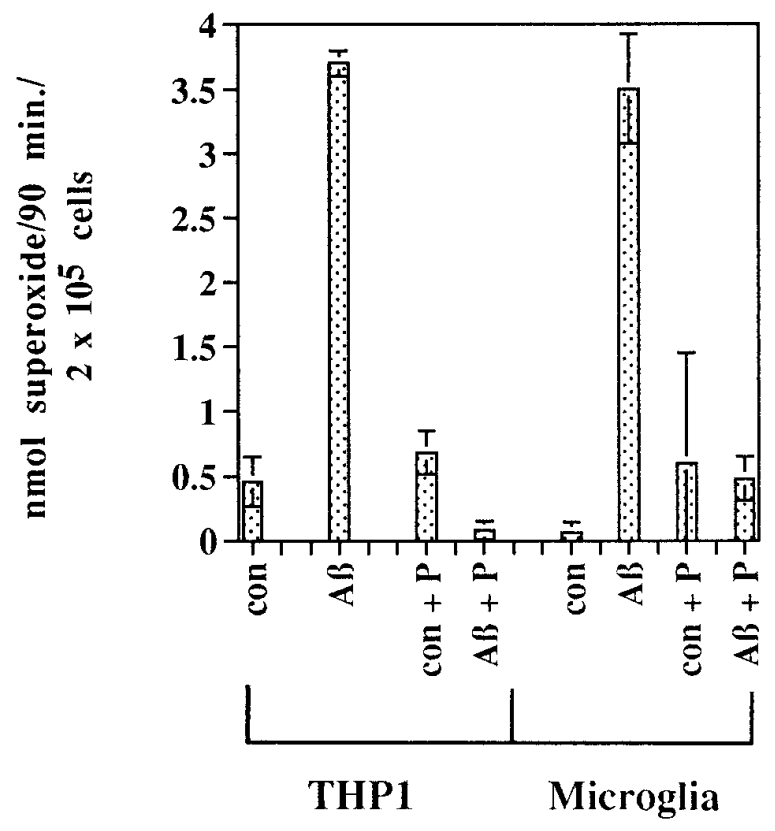

B.

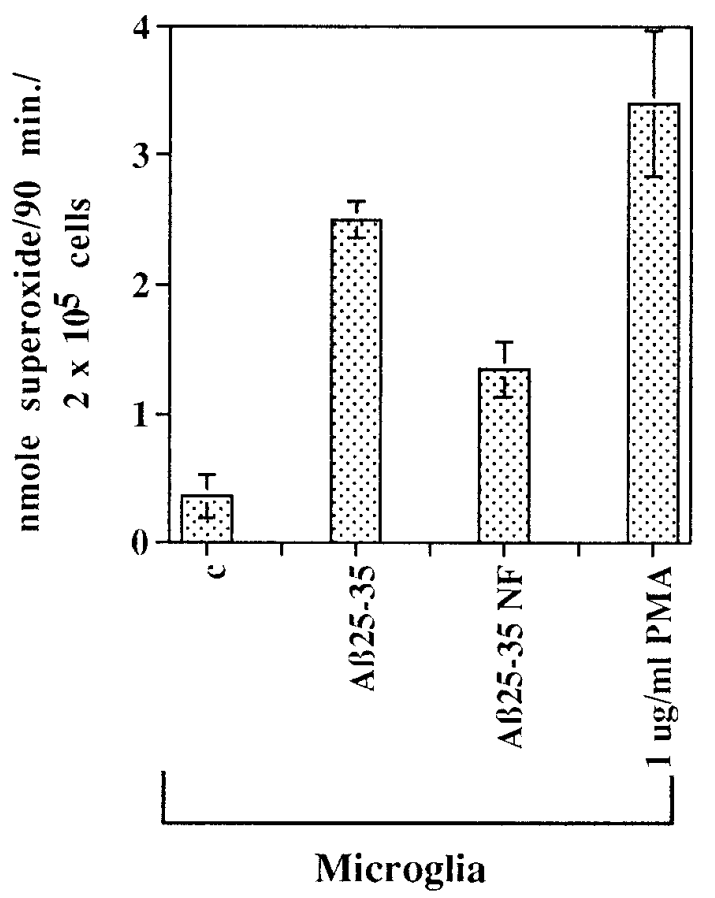

Figure 5. Fibrillar $\mathrm{A} \beta$ peptide stimulates respiratory burst in microglia and THP1 monocytes. $A$, Rat microglia were incubated in the absence $(c)$ or presence of 60 $\mu \mathrm{M}$ fibrillar $A \beta 1-40, A \beta 25-35$, or scrambled A $\beta 25-35$ $(S C 25-35)$. The peptides were added alone or in the presence of $40 \mu \mathrm{g}$ of superoxide dismutase (SOD), and $\mathrm{O}_{2}^{-}$production was measured. THP1 monocytes were incubated in absence $(c)$ or presence of $60 \mu \mathrm{M} A \beta 25-35$. $B$, Fibrillar, but not nonfibrillar, A $\beta 25-35$ stimulated release of $\mathrm{O}_{2}^{-}$from rat microglia. Microglia were incubated with $40 \mu \mathrm{M}$ fibrillar $A \beta 25-35$ or $40 \mu \mathrm{M}$ nonfibrillar A $\beta 25-35(A \beta 25-35 N F), 1 \mu \mathrm{g} / \mathrm{ml}$ phorbol myristate acetate $(P M A)$, or vehicle only $(c)$ in duplicate wells for 90 min. $C, \mathrm{~A} \beta 25-35$-stimulated release of $\mathrm{O}_{2}^{-}$from THP1 monocytes and microglia is blocked by piceatannol. Microglia and THP1 monocytes were pretreated for $1 \mathrm{hr}$ with $\pm 25 \mu \mathrm{g} / \mathrm{ml}$ piceatannol $(P)$. Cells were unstimulated (con) or stimulated for 90 min with $60 \mu \mathrm{M} \mathrm{A} \beta 25$ $35 \pm 25 \mu \mathrm{g} / \mathrm{ml}$ piceatannol. Supernatants were collected, and production of superoxide was determined spectrophotometrically by measurement of the reduction of ferricytochrome $\mathrm{C}$ at $550 \mathrm{~nm}$ and converted to moles of $\mathrm{O}_{2}^{-}$, using an extinction coefficient of $21 \times 10^{3} \mathrm{M}^{-1}$ $\mathrm{cm}^{-1}$. Production of $\mathrm{O}_{2}^{-}$is expressed as nanomole $\mathrm{O}_{2}^{-}$per 90 min per $2 \times 10^{5}$ cells.

\section{Effect of scavenger receptor and advanced glycation end product receptor ligands on tyrosine phosphorylation and respiratory burst}

Recently, $\mathrm{A} \beta$ was shown to interact at the cell surface with class $A$ scavenger receptors and the receptor for advanced glycation end products (RAGE; El Khoury et al., 1996; Yan et al., 1996), both of which have been linked to the production of reactive oxygen species. RAGE is postulated to immobilize $\mathrm{A} \beta$ at the cell surface, where $\mathrm{A} \beta$ then generates reactive oxygen species extracellularly (Hensley et al., 1994). The scavenger receptor, which binds both $\mathrm{A} \beta$ and advanced glycation end products, has been shown to mediate adhesion of microglia to $\mathrm{A} \beta$, resulting in the generation of reactive oxygen species. The intracellular signal transduction pathways activated by scavenger receptors are not well described, and RAGE has not been shown to be linked to signaling pathways or to elicit cellular effects. We tested whether binding of $\mathrm{A} \beta$ to 
A.

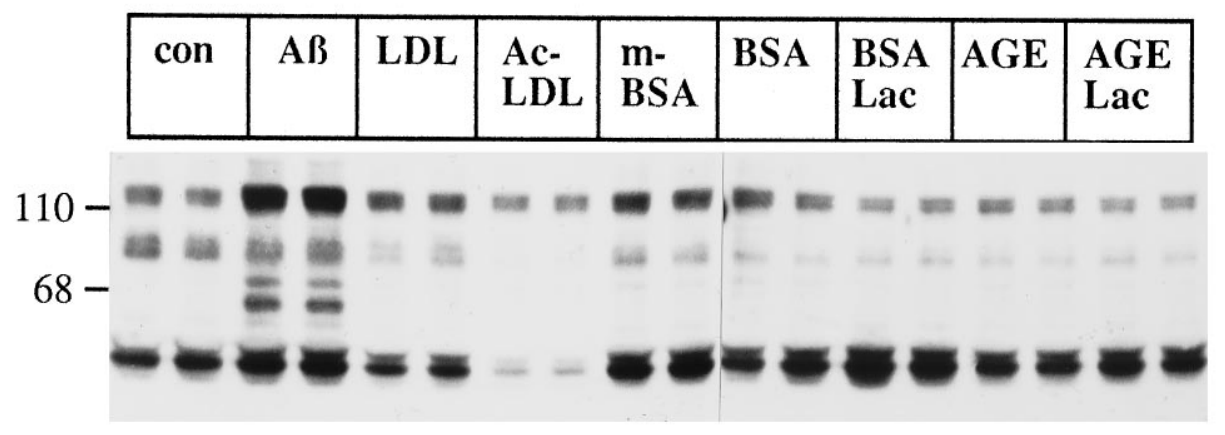

B.

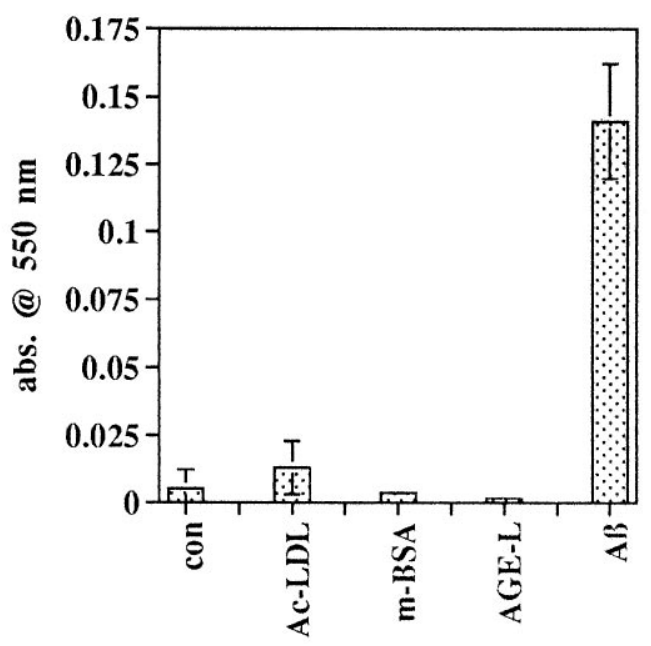

Figure 6. Effect of scavenger receptor and RAGE ligands on protein tyrosine phosphorylation and intracellular respiratory burst. $A$, THP1 monocytes were stimulated with $50 \mu \mathrm{M} \mathrm{A} \beta 25-35(A \beta)$ or $20 \mu \mathrm{g} / \mathrm{ml}$ of $L D L$, acetylated LDL ( $A c$ $L D L)$, maleylated BSA ( $m-B S A), B S A$, BSA plus lactoferrin ( $B S A L a c)$, glycated BSA $(A G E)$, or glycated BSA plus lactoferrin ( $A G E L a c$ ) for $2 \mathrm{~min}$ in HBSS. Cells were lysed in RIPA buffer, equal quantities of protein $(50 \mu \mathrm{g})$ were resolved by SDS-PAGE, and proteins were transferred to PVDF. Tyrosinephosphorylated proteins were detected by Western blot with 4 G10. $B$, THP1 monocytes were stimulated with $50 \mu \mathrm{M}$ A $\beta 25-35(A \beta)$ acetylated LDL $(A c-$ $L D L)$, maleylated BSA ( $m-B S A)$, or glycated BSA plus lactoferrin $(A G E-L)$ for $10 \mathrm{~min}$ in HBSS containing nitroblue tetrazolium. Cells were pelleted, supernatants were removed, and cells were lysed by sonication in RIPA buffer. Generation of superoxide was measured by the change in absorbance of reduced NBT at $550 \mathrm{~nm}$. these receptors was likely to be responsible for activation of tyrosine kinases and subsequent generation of reactive oxygen species. THP1 monocytes were exposed to the scavenger receptor ligands, maleylated-BSA and acetylated-LDL, and the RAGE ligand, glycated BSA in combination with iron-saturated lactoferrin. These ligands failed to elicit de novo increases in protein tyrosine phosphorylation. Conversely, $\mathrm{A} \beta$ stimulated dramatic increases in protein tyrosine phosphorylation of multiple proteins (Fig. $6 A$ ). Because $\mathrm{A} \beta$ and glycated proteins have been postulated to generate oxygen radicals (Sakurai and Tsuchiya, 1988; Hensley et al., 1994) spontaneously, the intracellular reduction of NBT was used to assay cell-dependent generation of superoxide (Pick, 1986). A $\beta$ was a potent stimulus of generation of intracellular superoxide radicals. We were unable to detect scavenger receptor ligand and RAGE ligand-stimulated intracellular superoxide production (Fig. 6B). We were, however, able to measure a modest level of scavenger receptor-mediated superoxide production from phorbol ester-differentiated THP1 monocytes (data not shown). These data indicate that $\mathrm{A} \beta$ is likely to activate different signaling pathways in monocytic cells than classical scavenger receptor and RAGE ligands. Also, we have been unable to implicate Fc $\gamma$ RI, Fc $\gamma$ RII, and tachykinin receptors directly in this response (data not shown). The identity of the microglial receptor(s) subserving these rapid effects of fibrillar $\mathrm{A} \beta$ remains unknown.

\section{DISCUSSION}

We report that microglia are able selectively to detect fibrillar forms of $\mathrm{A} \beta$, resulting in the activation of intracellular signaling cascades. These observations provide an important mechanistic link in understanding how these cells acquire an activated phenotype in the AD brain. It is of particular interest that the signaling pathways activated in response to $\mathrm{A} \beta$ also are used by these cells (and other cells of this lineage) to respond to conventional immune stimuli and result in common biological effects such as cytokine secretion (Debets et al., 1988) and superoxide production (Pfefferkorn and Fanger, 1989). Macrophages and microglia express a complex set of cell-surface proteins that mediate inflammatory responses to a wide variety of immune stimuli. Scavenger receptors or RAGE does not seem to mediate the rapid effects of $\mathrm{A} \beta$ on the activation of tyrosine kinases and downstream signaling events leading to the generation of superoxide. These data provide evidence that $\mathrm{A} \beta$ may interact with other membrane proteins linked to intracellular signal transduction pathways. These findings also suggest that scavenger receptor and RAGE occupancy elicit the production of reactive oxygen species through mechanistically distinct pathways that have not been defined.

Activation of tyrosine kinases of the src family, such as Lyn and Lck, is an initial step in signal transduction cascades of several 
immune responses in monocytes, macrophages, and lymphocytes. Stimulation of microglia and THP1 monocytes with $\mathrm{A} \beta$ also has led to activation of Lyn. Lyn is associated constitutively with the cytoplasmic domain of the Fc $\gamma$ RII (Ghazizadeh et al., 1994) receptor as well as the gamma subunit of Fc $\gamma \mathrm{RI}$ and Fc $\epsilon \mathrm{RI}$ (Wang et al., 1994) and becomes activated on clustering of the receptors by immune complexes. Lyn then phosphorylates these receptors on two tyrosine residues within the tyrosine activation motif (TAM), allowing the interaction and activation of downstream effector molecules such as members of Syk/ZAP70 tyrosine kinase family (Burkhardt et al., 1994; Shiue et al., 1995).

The tyrosine kinases of the Syk/ZAP70 family are also critical components for several immune responses in monocytes, macrophages, and lymphocytes and have been shown to be essential to B-cell maturation (Cheng et al., 1995; Turner et al., 1995; Crowley et al., 1996). Syk is activated by binding to phosphotyrosine residues within TAMs present on the cytoplasmic domain of the receptor or receptor subunits (Shiue et al., 1995). It is also possible that Syk may be activated by a direct interaction with Lyn, because Syk has been shown to be coimmunoprecipitated with Lyn (Sidorenko et al., 1995).

Syk has been shown to be essential for phagocytosis of immune complexes (Indik et al., 1995). Exposure of microglia and THP1 monocytes to $\mathrm{A} \beta$ led to tyrosine phosphorylation of $\mathrm{p} 72^{\mathrm{Syk}}$. It is not known, however, whether the A $\beta$-stimulated activation of Syk represents an early step in the phagocytosis of $\mathrm{A} \beta$ by microglia. Microglia in culture have been shown to be capable of phagocytosis of A $\beta$ (Frackowiak et al., 1992); however, it remains unclear whether microglia are capable of phagocytosing $\mathrm{A} \beta$-comprising senile plaques (Frautschy et al., 1992; el-Hachimi and Fonchin, 1994).

The tyrosine kinase inhibitor, piceatannol, has been shown to inhibit Syk (Oliver et al., 1994) selectively. The specific action of this drug has established the requirement for Syk in the $\operatorname{IgE}$ stimulated release of serotonin from RBL-2H3 rat mast cells. We have observed that one of the biological consequences of microglial interactions with $\mathrm{A} \beta$ is the activation of an inflammatory response, evidenced by the generation of superoxide radicals. Superoxide radicals are produced via the action of NADPH oxidase, a multisubunit complex, the assembly of which is stimulated by extracellular stimuli. Significantly, protein tyrosine phosphorylation has been shown to be critical for the activation of NADPH oxidase, presumably via activation of downstream signaling cascades, including the MAP kinases (Dusi et al., 1994). Phosphosphorylation of $\mathrm{p} 47^{\text {phox }}$ is essential for the assembly of the NADPH oxidase complex (Curnutte et al., 1994). The A $\beta$ stimulated production of superoxide radicals was arrested by pretreatment of microglia and THP1 monocytes with piceatannol. Therefore, inhibition of the activity of Syk or other elements within this signaling pathway represents molecular targets for blockade of microglial inflammatory responses to $\mathrm{A} \beta$.

FAK has been shown to be involved in regulating integrinmediated cellular adhesion and migration. Activation of FAK is known to occur at focal adhesions and mediates the assembly of large protein complexes linking the cytoskeleton to membrane signal transduction machinery in numerous cell types (Clark and Brugge, 1995), including monocytes (Lin et al., 1995). Microglia are the predominant cell type found within the core of senile plaques, suggesting that microglia must migrate to and interact with components of the plaques. We have demonstrated that the interaction of microglia and THP1 monocytes with either surfacebound fibrillar $\mathrm{A} \beta$ or fibrillar $\mathrm{A} \beta$ in solution stimulated the tyrosine phosphorylation of FAK. Thus, it is likely that activation of FAK is involved in microglial adhesion to and migration on $\mathrm{A} \beta$ within senile plaques. In addition, $\mathrm{A} \beta$-stimulated tyrosine phosphorylation of FAK may affect its interactions with other components of the $\mathrm{A} \beta$-stimulated signal transduction pathway by serving as a site for the formation of signaling complexes (Clark and Brugge, 1995).

A consequence of microglial $\mathrm{A} \beta$ interactions is the activation of a complex signal transduction cascade resulting in the production of superoxide, which was found to be dependent on interaction of the cells with fibrillar conformations of $\mathrm{A} \beta$. This finding is significant, because $\mathrm{AD}$ pathology is associated with mature senile plaques possessing $\mathrm{A} \beta$ in a fibrillar or $\beta$-pleated sheet conformation. In addition, other investigators have found that the biological effects of $\mathrm{A} \beta$, such as neurotoxicity (Pike et al., 1990) and stimulation of IL- $1 \beta$ release from THP1 monocytes (Lorton et al., 1996), are dependent on a fibrillar conformation of the peptide. It is unlikely that the responses to fibrillar $\mathrm{A} \beta$ described here are mediated by RAGE, because it was identified on the basis of its ability to bind $\mathrm{A} \beta$ monomers.

Importantly, previous activation of microglia and THP1 monocytes was not necessary for $\mathrm{A} \beta$ to induce release of superoxide. The ability of $\mathrm{A} \beta$ to elicit the production of reactive oxygen species is consistent with a previous report showing that $\mathrm{A} \beta$ stimulated the release of $\mathrm{NO}_{2}^{-}$from primary cultures of rodent microglia (Meda et al., 1995). However, the latter response was entirely dependent on priming microglia with INF $\gamma$. In addition, the role of $\mathrm{NO}_{2}^{-}$in human macrophage responses to inflammatory stimuli remains controversial (Albina, 1995), and recent studies have failed to detect iNOS mRNA in cultures of activated human microglia (Walker et al., 1995). The present data demonstrate that $\mathrm{A} \beta$ alone is sufficient to activate complex intracellular signaling processes in microglia, resulting in the release of toxic inflammatory products, and support a role for oxidative damage in the pathogenesis of AD.

Recently, RAGE and scavenger receptors have been shown to interact with $\mathrm{A} \beta$ at the cell surface, where the peptide may elicit potentially harmful responses in microglia and neurons via generation of reactive oxygen species (El Khoury et al., 1996; Yan et al., 1996). However, occupancy of these receptors with saturating quantities of their specific ligands does not stimulate changes in protein tyrosine phosphorylation or intracellular $\mathrm{O}_{2}^{-}$production, in contrast to the effect of $\mathrm{A} \beta$. RAGE is believed to act as a tether that binds $\mathrm{A} \beta$ to cell surfaces, where reactive oxygen species are generated extracellularly by an undefined mechanism. In contrast, the data presented here demonstrate that fibrillar $\mathrm{A} \beta$ activates signal transduction pathways in microglia, leading to intracellular generation of superoxide as well as its release in the extracellular space (Figs. 5, 6). Although $\mathrm{A} \beta$ has been shown to interact with scavenger receptors and RAGE, the present data demonstrate that these receptors do not mediate the activation of tyrosine kinases and generation of superoxide detected here. Moreover, these data provide evidence for the existence of other $\mathrm{A} \beta$ interactive species that are linked to the signal transduction pathways in these cells. However, it remains possible that fibrillar A $\beta$ may bind scavenger receptors or RAGE but activate intracellular processes distinct from natural ligands, including acetylated LDL and glycated BSA, respectively.

These data provide support for the view that the pathogenesis of $\mathrm{AD}$ comprises a series of events initially characterized by the production of $A \beta$, aggregation of $A \beta$ into fibrils, and deposition of $\mathrm{A} \beta$ fibrils as extracellular plaques within the brain. Microglia 
initially interact with $\mathrm{A} \beta$ fibrils and initiate a rapid, complex cellular response, resulting in the elaboration of potentially toxic products, including reactive oxygen intermediates. The elaboration of cytokines and other mediators of inflammation, such as complement components, proteases, and protease inhibitors, then may generate a feed-forward inflammatory process. The progressive neuropathological changes in the AD brain and the accompanying deterioration in cognitive ability are likely to be, in part, a consequence of ongoing local inflammatory responses in the brain mediated by microglia. Inflammation, generation of reactive oxygen intermediates, and cytokine release are recurring mechanisms in the pathophysiology of many neurodegenerative diseases (Halliwell, 1992; Brown et al., 1996; Lorton et al., 1996). Indeed, the hypothesis that $\mathrm{AD}$ pathogenesis involves an ongoing inflammatory response is supported by recent epidemiological analysis demonstrating that long-term anti-inflammatory drug treatment is correlated with a lower incidence of dementia (McGeer and McGeer, 1996).

\section{REFERENCES}

Abraham CR, Selkoe DJ, Potter H (1988) Immunochemical identification of the serine protease inhibitor $\alpha_{1}$-antichymotrypsin in the brain amyloid deposits of Alzheimer disease. Cell 52:487-501.

Agarwal A, Salem P, Robbins KC (1993) Involvement of p72 $2^{\text {syk }}$, a protein tyrosine kinase, in $\mathrm{Fc} \gamma$ receptor signaling. $\mathrm{J}$ Biol Chem 268:15900-15905.

Albina JE (1995) On the expression of nitric oxide synthase by human macrophages. Why no NO? J Leukoc Biol 58:643-649.

Araujo DM, Cotman CW (1992) $\beta$-Amyloid stimulates glial cells in vitro to produce growth factors that accumulate in senile plaques in Alzheimer's disease. Brain Res 569:141-145.

Bauer J, Strauss S, Scheiter-Gasser U, Ganter U, Shlegel P, Witt I, Yolk B, Berger M (1991) Interleukin-6 and alpha-2-macroglobulin indicate an acute phase in Alzheimer's disease cortices. FEBS Lett 285:111-114.

Bellis SL, Miller JT, Turner CE (1995) Characterization of tyrosine phosphorylation of paxillin in vitro by focal adhesion kinase. $\mathrm{J}$ Biol Chem 270:17437-17441.

Bradford MM (1976) A rapid and sensitive method for the quantitation of microgram quantities of protein utilizing the principle of protein-dye binding. Anal Biochem 72:248-254.

Brown DR, Schmidt B, Kretzschmar HA (1996) Role of microglia and host prion protein in neurotoxicity of a prion protein fragment. Nature 380:345-347.

Burkhardt AL, Saouaf SJ, Mahajan S, Bolen JB (1994) Involvement of nonreceptor protein tyrosine kinases in multichain immune recognition receptor signal transduction. Adv Exp Med Biol 365:131-141.

Cataldo AM, Nixon RA (1990) Enzymatically active lysosomal proteases are associated with amyloid deposits in Alzheimer brain. Proc Natl Acad Sci USA 87:3861-3865.

Cheng AM, Rowley B, Pao W, Hayday A, Bolen JB, Pawson T (1995) Syk tyrosine kinase required for mouse viability and B-cell development. Nature 378:303-306.

Clark EA, Brugge JS (1993) Redistribution of activated pp60 $0^{\mathrm{src}}$ to integrin-dependent cytoskeletal complexes in thrombin-stimulated platelets. Mol Cell Biol 13:1863-1871.

Clark EA, Brugge JS (1995) Integrins and signal transduction pathways: the road taken. Science 268:233-239.

Cole GM, Huynh TV, Saitoh T (1989) Evidence for lysosomal processing of amyloid beta-protein precursor in cultured cells. Neurochem Res 10:933-939.

Crowley MT, Harmer SL, DeFranco AL (1996) Activation-induced association of a $145 \mathrm{kDa}$ tyrosine-phosphorylated protein with Shc and Syk in B-lymphocytes and macrophages. J Biol Chem 271:1145-1152.

Curnutte JT, Erickson RW, Ding J, Badwey JA (1994) Reciprocal interactions between protein kinase $\mathrm{C}$ and components of the NADPH oxidase complex may regulate superoxide production by neutrophils stimulated with phorbol ester. J Biol Chem 269:10813-10819.

Debets JM, Van der Linden CJ, Dieteren IE, Leeuwenberg JF, Buurman WA (1988) Fc-receptor cross-linking induces rapid secretion of tumor necrosis factor (cachectin) by human peripheral blood monocytes. J Immunol 141:1197-1201.
Dusi S, Donini M, Rossi F (1994) Tyrosine phosphorylation and activation of neutrophils: a possible role for MAP kinases and for a $75 \mathrm{kDa}$ protein. Biochem J 304:243-250. el-Hachimi KH, Fonchin JF (1994) Do microglial cells phagocytose the beta/A4-amyloid senile plaque core of Alzheimer disease? C R Acad Sci III 317:445-451.

El Khoury J, Hickman SE, Thomas CA, Cao L, Silverstein SC, Loike JD (1996) Scavenger receptor-mediated adhesion of microglia to $\beta$-amyloid fibrils. Nature 382:716-719.

Frackowiak J, Wisniewski HM, Wegiel J, Merz GS, Iqbal K, Wang KC (1992) Ultrastructure of the microglia that phagocytose amyloid and the microglia that produce beta-amyloid fibrils. Acta Neuropathol (Berl) 84:225-233.

Frautschy SA, Cole GM, Baird A (1992) Phagocytosis and deposition of vascular beta-amyloid in rat brains injected with Alzheimer beta amyloid. Am J Pathol 140:1389-1399.

Furuta Y, Ilic D, Kanazawa S, Takeda N, Yamamoto T, Aizawa S (1995) Mesodermal defect in late phase of gastrulation by a targeted mutation of focal adhesion kinase, FAK. Oncogene 11:1989-1995.

Ghazizadeh S, Bolen JB, Fleit HB (1994) Physical and functional association of Src-related protein tyrosine kinases with Fc gamma RII in monocytic THP-1 cells. J Biol Chem 269:8878-8884.

Giulian D, Baker TJ (1986) Characterization of ameboid microglia isolated from developing mammalian brain. J Neurosci 6:2163-2178.

Glenner GC, Wong CW (1984) Initial report of the purification and characterization of a novel cerebrovascular amyloid protein. Biochem Biophys Res Commun 120:885-890.

Golde TE, Estus S, Younkin LH, Selkoe DJ, Younkin SG (1992) Processing of the amyloid protein precursor to potentially amyloidogenic derivatives. Science 255:728-730.

Greenburg S, Chang P, Silverstein SC (1994) Tyrosine phosphorylation of the $\gamma$ subunit of $\mathrm{Fc} \gamma$ receptors, $\mathrm{p} 72^{\mathrm{syk}}$, and paxillin during Fc receptor-mediated phagocytosis in macrophages. $J$ Biol Chem 269:3897-3902.

Griffin W, Stanley L, Ling C (1989) Brain interleukin 1 and S-100 immunoreactivity are elevated in Down syndrome and Alzheimer disease. Proc Natl Acad Sci USA 86:7611-7615.

Guan JL, Shalloway D (1992) Regulation of focal adhesion-associated protein tyrosine kinase by both cellular adhesion and oncogenic transformation. Nature 358:690-692.

Haberland ME, Fogelman AM (1985) Scavenger receptor-mediated recognition of maleyl bovine plasma albumin and the demaleylated protein in human monocyte macrophages. Proc Natl Acad Sci USA 82:2693-2697.

Halliwell B (1992) Reactive oxygen species and the central nervous system. J Neurochem 59:1609-1623.

Hamawy MM, Minoguchi K, Swaim WD, Mergenhagen SE, Siraganian RP (1995) A $77 \mathrm{kDa}$ protein associates with pp $125^{\mathrm{FAK}}$ in mast cells and becomes tyrosine-phosphorylated by high affinity $\operatorname{IgE}$ receptor aggregation. J Biol Chem 270:12305-12309.

Hensley K, Carney JM, Mattson MP, Aksenova M, Harris M, Wu JF, Floyd RA, Butterfield DA (1994) A model for $\beta$-amyloid aggregation and neurotoxicity based on free radical generation by the peptide: relevance to Alzheimer disease. Proc Natl Acad Sci USA 91:3270-3274.

Ilic D, Furuta Y, Kanazawa S, Takeda N, Sobue K, Nakatsuji N, Nomura S, Fujimoto J, Okada M, Yamamoto T, Aizawa S (1995) Reduced cell motility and enhanced focal adhesion contact formation in cells from FAK-deficient mice. Nature 377:539-544.

Indik ZK, Park JG, Pan ZQ, Schreiber AD (1995) Induction of phagocytosis by a protein tyrosine kinase. Blood 85:1175-1180.

Itagaki S, McGeer PL, Akiyama H, Zhu S, Selkoe D (1989) Relationship of microglia and astrocytes to amyloid deposits of Alzheimer disease. J Neuroimmunol 24:173-182.

Kiener PA, Rankin BM, Burkhardt AL, Schieven GL, Gilliland LK, Rowley RB, Bolen JB, Ledbetter JA (1993) Cross-linking of Fc $\gamma$ receptor I $(\mathrm{Fc} \gamma \mathrm{RI})$ and receptor II $(\mathrm{Fc} \gamma \mathrm{RII})$ on monocytic cells activates a signal transduction pathway common to both Fc receptors that involves the stimulation of $\mathrm{p} 72^{\text {Syk }}$ protein tyrosine kinase. J Biol Chem 268:24442-24448.

Lagenaur C, Lemmon V (1987) An L1-like molecule, the 8D9 antigen, is a potent substrate for neurite extension. Proc Natl Acad Sci USA 84:7753-7757.

Leong SK, Ling E-A (1992) Ameboid and ramified microglia: their interrelationship and response to brain injury. Glia 7:39-47.

Lin TH, Rosales C, Mondal K, Bolen JB, Haskill S, Juliano RL (1995) 
Integrin-mediated tyrosine phosphorylation and cytokine message induction in monocytic cells. J Biol Chem 270:16189-16197.

Lorton D, Kocsis J-M, King L, Madden K, Brunden KR (1996) $\beta$-Amyloid induces increased release of interleukin $1 \beta$ from lipopolysaccharideactivated human monocytes. J Neuroimmunol 67:21-29.

Masters CL, Simms G, Weinman NA, Multhaup G, McDonald BL, Beyreuther K (1985) Amyloid core protein in Alzheimer's disease and Down syndrome. Proc Natl Acad Sci USA 82:4245-4249.

McGeer PL, McGeer EG (1996) Anti-inflammatory drugs in the fight against Alzheimer's disease. Ann NY Acad Sci 777:213-220.

McGeer PL, Akiyama H, Itagaki S, McGeer EG (1989) Immune system response in Alzheimer's disease. Can J Neurol Sci 16:516-527.

McGeer PL, Kawamata T, Walker DG, Akiyama H, Tooyama I, McGeer EG (1993) Microglia in degenerative neurological diseases. Glia 7:84-92.

Meda L, Cassatella MA, Szendrei GI, Otovos L, Baron P, Villalba M, Ferrari D, Rossi F (1995) Activation of microglial cells by $\beta$-amyloid protein and interferon $\gamma$. Nature 374:647-650.

Minoguchi K, Kihara H, Nishikata H, Hamawy MM, Siraganian RP (1994) Src family tyrosine kinase Lyn binds several proteins including paxillin in rat basophilic leukemia cells. Mol Immunol 31:519-529.

Oliver JM, Burg DL, Wilson BS, McLaughlin JM, Geahlen RL (1994) Inhibition of mast cell $\mathrm{Fc}$ epsilon R1-mediated signaling and effector function by the Syk selective inhibitor, piceatannol. J Biol Chem 269:29697-29703.

Pfefferkorn LC, Fanger MW (1989) Cross-linking of the high affinity Fc receptor for human immunoglobulin G1 triggers transient activation of NADPH oxidase activity. J Biol Chem 264:14112-14120.

Pick E (1986) Microassays for superoxide and hydrogen peroxide production and nitroblue tetrazolium reduction using an enzyme immunoassay microplate reader. Methods Enzymol 132:407-421.

Pike CJ, Burdick D, Walencewicz AJ, Glabe CG, Cotman CW (1990) Neurodegeneration induced by $\beta$-amyloid peptides in vitro: the role of peptide assembly state. J Neurosci 13:1676-1687.
Sakurai T, Tsuchiya S (1988) Superoxide production from nonenzymatically glycated protein. FEBS Lett 236:406-410.

Selkoe DJ (1991) The molecular pathology of Alzheimer's disease. Neuron 6:915-922.

Selkoe DJ (1996) Amyloid $\beta$-protein and the genetics of Alzheimer's disease. J Biol Chem 271:18295-18298.

Shiue L, Zoller MJ, Brugge JS (1995) Syk is activated by phosphotyrosine-containing peptides representing the tyrosine-based activation motifs of the high affinity receptor for IgE. J Biol Chem 270:10498-10502.

Sidorenko SP, Law C-L, Chandran KA, Clark EA (1995) Human spleen tyrosine kinase $\mathrm{p} 72^{\mathrm{Syk}}$ associates with the Src-family kinase $\mathrm{p} 53 / \mathrm{p} 56^{\mathrm{Lyn}}$ and a $120 \mathrm{kDa}$ phosphoprotein. Proc Natl Acad Sci USA 92:359-363.

Terzi E, Holzemann G, Seelig J (1994) Reversible random coil- $\beta$-sheet transition of the Alzheimer $\beta$-amyloid fragment (25-35). Biochemistry 33:1345-1350.

Turner M, Mee PJ, Costello PS, Williams O, Price AA, Duddy LP, Furlong MT, Geahlen RL, Tybulewicz VL (1995) Perinatal lethality and blocked B-cell development in mice lacking the tyrosine kinase Syk. Nature 378:298-302.

Walker DG, Kim SU, McGeer PL (1995) Complement and cytokine expression in cultured microglia derived from postmortem human brains. J Neurosci Res 40:478-493.

Wang AV, Scholl PR, Geha RS (1994) Physical and functional association of the high affinity immunoglobulin $\mathrm{G}$ receptor ( $\mathrm{Fc}$ gamma $\mathrm{RI})$ with the kinases Hck and Lyn. J Exp Med 180:1165-1170.

Wood J, Zinsmeister P (1991) Tyrosine phosphorylation systems in Alzheimer's disease pathology. Neurosci Lett 121:12-16.

Yan SD, Chen X, Fu J, Chen M, Zhu H, Roher A, Slattery T, Zhao L, Nagashima M, Morser J, Migheli A, Nawroth P, Stern D, Schmitt AM (1996) RAGE and amyloid- $\beta$ peptide neurotoxicity in Alzheimer's disease. Nature 382:685-691. 